удК 658.511 .5

\title{
ВИКОРИСТАННЯ ВИРОБНИЧОЇ ПОТУЖНОСТІ НА ПОЛІГРАФІЧНИХ ПІДПРИЕМСТВАХ
}

( Л. П. Шендерівська, ст. викладач, О. Ю. Аладьєва, бакалавр, НТУУ «КПІ», Київ, Україна

Обозначены основные аспекты производственной мощности и ее значения для развития предприятия. На основе группы полиграфических предприятий был осуществлен анализ производственной мощности, установлена степень ее использования с помощью ряда показателей и нахождения основных путей улучшения.

Exposure basic aspects of production capacity and its value for development of enterprise. On the basis of group of printeries the analysis of production capacity was carried out, the degree of its use is set by the row of indexes and finding of basic ways of improvement.

\section{Постановка проблеми}

Виробнича потужність характеризує потенційні можливості підприємства з досягнення основної об'єктивної мети його виробничо-господарської діяльності. Найважливішим результатом організації інтенсивного використання виробничих потужностей $є$ прискорення темпів приросту продукції без додаткових капіталовкладень, темпів росту фондовіддачі. При вдосконалюванні інтенсивного використання виробничих потужностей необхідно враховувати два фактора, що обумовлюють можливість більш напруженого функціонування потужностей ресурсів у часі (підвищення їхнього завантаження) і потужностей, що роблять вплив на інтенсивний приріст. При дослідженні виробничої потужності поліграфічних підприємств були виявленні фактори впливу та основні шляхи покращення показника.

\section{Аналіз попередніх} досліджень

Загальні питання виробничої потужності ґрунтовно опрацьовані у роботах Г. М. Тарасюка [9], В. К. Скляренко [8], А. В. Шегди [11]. Основними напрямами досліджень $є$ : підвищення ефективності, аналіз змін та управління виробничими потужностями у машинобудівній, нафтопереробній, кондитерській галузях представлених у роботах Майстренко О. М., Мазур І. М., Мощинської В. А., Распопова Р. С., Богославця О. І., Череп А. Ю., та інші. Мало уваги приділено дослідженню виробничої потужності у поліграфії тому залишається ряд невирішених питань.

\section{Мета роботи}

Проаналізувати використання виробничої потужності поліграфічних підприємств за допомогою обраної методики та визначити основні тенденції розвитку. 


\section{Результати проведених досліджень}

Виробнича потужність має динамічну природу: вона формує потенціал з отримання доходу, водночас незадіяні потужності негативно впливають на фінансові результати підприємства. Із множини визначень виробничої потужності, на нашу думку, найточніше відображає економічну природу даної категорії трактування: виробнича потужність підприємства - це максимально можливий випуск продукції необхідної якості в передбаченій номенклатурі за певний час (зміну, добу, місяць, рік) при повному завантаженні обладнання та виробничих площ у прийнятому режимі роботи з урахуванням застосування передової технології, організації виробництва і праці [11]. Порівнюючи методики класифікації виробничої потужності можна визначити декілька. На думку Скляренко В. К. та Подкропивного С. Ф. виробничу потужність доцільно класифікувати за такими ознаками:

1) за рівнем розрахунку:

- конкретного устаткування або укрупненої групи;

- конкретного підрозділу підприємства;

- конкретного підприємства в цілому;

2) за видами:

- проектна;

- поточна;

- резервна $[6,8,10]$.

За іншою класифікацією розрізняють такі види виробничої потужності, як перспективну, проектну та діючу.

Перспективна виробнича потужність відображає очікувані зміни номенклатури продукції, технології й організації виробництва, закладені в плановому періоді.

Проектна виробнича потужність являє собою величину можливого випуску продукції умовної номенклатури в одиницю часу, задану при проектуванні чи реконструкції виробничої одиниці [1]. Вона $€$ фіксованою величиною тому, що розрахована на постійну умовну номенклатуру і постійний режим роботи. За період проектування (1-2 роки), будівництва (2-5 років) і освоєння потужності (1-2 роки) значно змінюється номенклатура продукції, що випускається, а також ряд технологічних характеристик устаткування. Тому проектна потужність перестає відображати дійсні можливості підприємства.

Діюча потужність підприємства (цеху, лінії, агрегату) показує його потенційну здатність виробити протягом календарного періоду максимально можливу кількість продукції, передбаченої планом. Вона має динамічний характер і змінюється відповідно до організаційнотехнічного розвитку виробництва. Тому її характеризують кілька показників [1]:

- потужність на початок планового періоду (вхідна);

- потужність на кінець планового періоду (вихідна);

- середньорічна потужність.

На наш погляд друга класифікація є більш повною, оскільки відображає всі зміни виробничої потужності, які можуть відбуватися на підприємстві. Оскільки завдяки точному та правильному визначенню ви- 


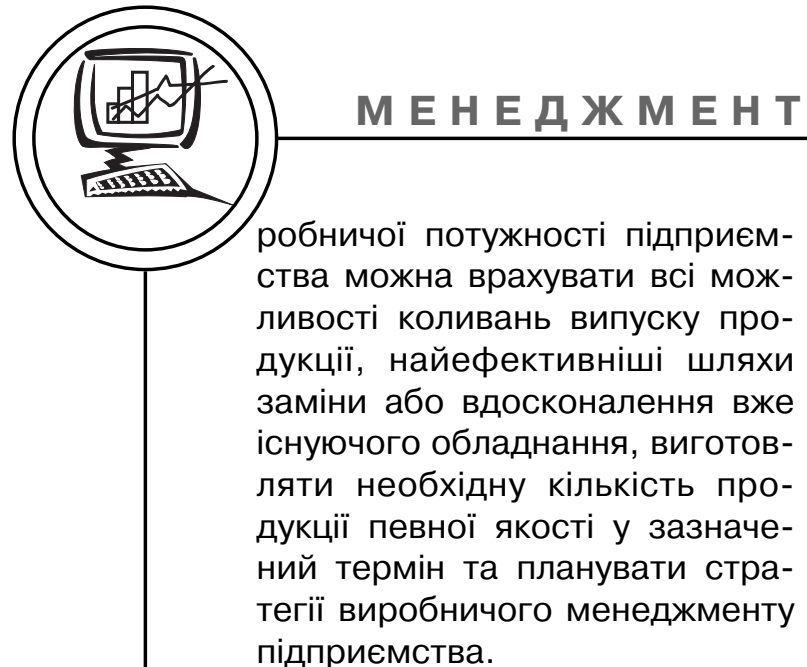

Для аналізу використання виробничої потужності можна виділити ряд показників, що класифікується по групах. До показників, які відображають ефективне використання виробничих потужностей на підприємстві належать [8]: коефіцієнт використання виробничої потужності $\left(\mathrm{K}_{\mathrm{N}}\right)$, коефіцієнт змінності устаткування $\left(\mathrm{K}_{3 \mathrm{~B}}\right)$, коефіцієнт напруженості використання устаткування (К ється виробнича потужність, як правило, у натуральних, умовно-натуральних одиницях або вартісних показниках. Використання натуральних показників для вимірювання виробничої потужності можливо тільки на вузькоспеціалізованих підприємствах, що випускають однорідну нескладну продукцію. При великій різноманітності продукції спорідненого призначення використовуються умовно-натуральні показники. Система вартісних показників застосовується для визначення обсягів реалізованої, товарної і валової продукції. У поліграфії застосовують умовно-натуральні одиниці виміру, через значну різноманітність асортиментної продукції. До цієї групи показників належить інтегральний показник, що в основному зале- жить від рівня технічного стану організації ремонтів та технічного переозброєння та дає сумарну характеристику рівня використання устаткування як за продуктивністю, так і за часом [2].

$$
\mathrm{K}_{\mathrm{iHT}}=\mathrm{K}_{\mathrm{e}} \times \mathrm{K}_{\mathrm{i}} \text {, }
$$

де $\mathrm{K}_{\mathrm{e}}$ - коефіцієнт екстенсивного використання обладнання (виробничої потужності; $\mathrm{K}_{\mathrm{i}}$ - коефіцієнт інтенсивного використання обладнання (виробничої потужності).

$$
\mathrm{K}_{\mathrm{e}}=\sum_{\mathrm{i}=1}^{\mathrm{m}} \mathrm{N}_{\mathrm{i}} \times \mathrm{T}_{\text {од. }} / \mathrm{T}_{\text {д. }},
$$

де $\mathrm{T}_{\text {од. }}$ - норма часу на обробку і-го виробу; $\mathrm{N}_{\mathrm{i}}$ - кількість виробів; $\mathrm{m}$ - кількість видів продукції, що обробляються; $\mathrm{T}_{д}$ дійсний фонд часу.

Коефіцієнт екстенсивного використання виробничих потужностей показує на зменшення простоїв машин та устаткування на підприємстві, чи зменшується кількість недієздатного та прискорюється виведення з експлуатації непотрібного устаткування, чи збільшується коефіцієнт змінності роботи виробничого устаткування за календарний проміжок часу.

$$
\mathrm{K}_{\mathrm{i}}=\sum_{\mathrm{i}=1}^{\mathrm{m}} \mathrm{N}_{\mathrm{i}} \times \mathrm{T}_{\mathrm{M} .} / \sum_{\mathrm{i}=1}^{\mathrm{m}} \mathrm{N}_{\mathrm{i}} \times \mathrm{T}_{\text {oд. }},
$$

де $\mathrm{T}_{\mathrm{M} .}$ - час машинної та машино-ручної обробки і-ї деталі.

Коефіцієнт інтенсивного використання виробничих потужностей показує як швидко на підприємстві впроваджуються нові ефективні технології, застосовуються прогресивні форми та методи організації вироб- 
ництва, як швидко здійснюється освоєння нових введених в дію технологій та устаткування [8].

Для характеристики використання виробничої потужності науковці пропонують використати: коефіціент змінності роботи обладнання ( $\left.\mathrm{K}_{\mathrm{cm}}\right)$, коефіцієнт завантаження обладнання (Кз), коефіцієнт середнього часу роботи обладнання (F), коефіцієнт пропорційності (Кпр).

Для оціники впливу інтенсивного використання виробничих потужностей на ефективність виробництва обґрунтовані такі методики:

- коефіцієнт приросту фондовіддачі $(\Delta \Phi)$, який дає змогу оцінити вплив завантаження обладнання на фондовіддачу:

$$
\Delta \Phi=\Phi_{б}\left(\frac{K_{3.0}}{K_{3 . б}}-1\right),
$$

де $\Delta \Phi-$ приріст фондовіддачі за рахунок підвищення завантаження обладнання; $\mathrm{K}_{3.0}$

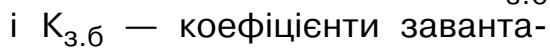
ження обладнання у звітному та базисному році; $Ф_{б}-\phi о н-$ довіддача у базисному році.

- резерви підвищення фондовіддачі, що дасть можливість поліпшення використання прийнятої потужності:

$$
P_{\phi}=\frac{\left(\Phi_{п р}-\Phi_{\text {м }}\right) \cdot 100}{\Phi_{\text {пр }}}
$$

де $\Phi_{п р}-$ величина фондовіддачі за проектом; $\Phi_{\mathrm{M}}-$ величина фондовіддачі по прийнятій потужності.

- показник, який характеризує ефективність використання активної частини основних фон- дів, є випуск продукції у розрахунку на одиницю вартості обладнання.

- коефіцієнт, що характеризує ефективність використання виробничих площ $[1,4,5]$.

Таким чином підходи до визначення виробничої потужності можна поділити на 3 групи:

- за кількістю продукції;

- за вартістю;

- за часом.

За допомогою цієї системи показників можна отримати достовірну інформацію про стан підприємства, на основі якої провести повний аналіз виробничих потужностей та встановити заходи, які необхідні для найефективнішого використання резервів виробничих потужностей та інтенсивності їх використання. Також слід звернути увагу на рівень кожного з показників і відповідно до результатів застосувати методики по зміні тактики ведення виробництва та функціонування підприємства в цілому. Так як за сутністю виробнича потужність - максимально можливий обсяг виробництва, то основним критерієм ефективності її використання має бути кількість продукції.

У поліграфії виробничу потужність в цілому по підприємству розраховують на базі потужності друкарського устаткування, як провідного за такою формулою:

$$
\begin{aligned}
& \mathrm{M}_{\text {в.п. }}=\left(\mathrm{T}_{\text {осн }} /\left(\mathrm{t}_{\text {прил. }}+\left(\mathrm{N} \times \mathrm{t}_{\text {др. }}\right) /\right.\right. \\
& \text { /60) }) \times N \times \Phi \times K_{\text {прив. }}
\end{aligned}
$$

або

$$
\begin{gathered}
\mathrm{M}_{\text {в.п. }}=\mathrm{T}_{\text {роб }} \times\left(60 / \mathrm{t}_{\text {др }}\right)=\mathrm{T}_{\text {роб}} / \\
/ \mathrm{H}_{\text {год }}
\end{gathered}
$$


де $\mathrm{T}_{\text {осн }}$ - основний час роботи устаткування тобто режимний час мінус ремонтні та технологічні зупинки (год.); $\mathrm{T}_{\text {роб - }}$ робочий час устаткування, тобто основний час мінус час при-

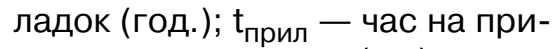
ладку устаткування (хв.); $\mathrm{t}_{\text {др }}$ час на друк накладу (хв.); $\mathrm{H}_{\text {год }}$ норма виробітку за годину; $\mathrm{N}-$ тираж замовлення; Ф- кількість фарбових секцій в машині; $\mathrm{K}_{\text {прив }}$ - коефіцієнт приведення максимального формату задруковуваної поверхні друкарської машини до $60 \times 90 \mathrm{~cm}$.

Для решти устаткування, крім друкарського, виробнича потужність обчислюється як відношення основного фонду часу до норми виробітку за годину.

На прикладі поліграфічних підприємств проаналізовано використання виробничої потужності. Не усі підприємства, 3 яких сформована вибірка функціонують на одному сегменті ринку, тому мають значні відмінності у масштабах діяльності та техніко-технологічному оснащенню. Таким чином можна виявити тенденцію в розрізі аналізованої економічної категорії спільну для різнопланових суб'єктів господарювання з більшою кількістю факторів варіативності. Для аналізу виробничої потужності підприємств були розраховані такі показники:

- Виробнича потужність додрукарських, друкарських та післядрукарських процесів;

- Рентабельність виробничої потужності;

- Коефіцієнт використання виробничої потужності;

- Коефіцієнт кореляції виробничої потужності та коефіцієнту її використання;
- Коефіцієнт пропорційності між цехами.

Результати розрахунків виробничої потужності по групі поліграфічних підприємств подані у табл. 1.

Ступінь зв'язку між рентабельністю виробничої потужності та коефіцієнтом використання потужності $\epsilon$ істотним (71\%).

Виробнича потужність окремих підприємств суттєво різниться. Найбільші потенційні можливості по виготовленню продукції має друкарня «БліцПринт». До початку кризи 2008 року вона займала лідируючі позиції. Наразі за умов жорсткої цінової конкуренції, незважаючи на режим економії, потужності незавантажені на 65 \%. Друкарня вживає комплекс антикризових заходів, має оптимістичний прогноз розвитку, т.ч. не прагне позбутися незадіяних виробничих потужностей.

Кагарлицька друкарня та Дніпрокварц є малими за масштабами діяльності, використовують морально застарілу технологію виготовлення друкарських форм, спрацьоване друкарське устаткування. Але потужностей достатньо для забезпечення відносно невисокого попиту на місцевому ринку. По друкарнях найменший з усіх аналізованих поліграфічних підприємств ступінь використання виробничої потужності головно з причини невисокої якості продукції.

Відносно низький рівень інтенсивного використання устаткування виявлений по підприємству «Техніка-лТД». За дещо триваліший ніж десять років досвід роботи на ринку компанія напрацювала постійних клієнтів. 
Але неповний виробничий цикл, недостатня увага до технічного переоснащення гальмують стратегію розширення діяльності.

Групу підприємств, які спеціалізуються на виготовленні журнальної продукції складають «Новий Друк» та «Укрполіграфмедіа». За потужністю, ступенем її використання вони кардинально відрізняються. «Новий друк» має позитивний імідж виробника продукції належної якості. Сучасне високопродуктивне обладнання дозволяє тиражувати продукцію з невисокими питомими витратами. Зазначені чинники формують успіх друкарні на ринку. «Укрполіграфмедіа», хоча і функціонує на одному з найбільш стабільних сегментів - журнальної продукції, за показниками ритмічності роботи, оперативності, якості продукції, поступається конкурентам, як наслідок має втрати від недовикористання виробничої потужності.

«Бізнес-Поліграф» спеціалізується на виготовленні книжкової продукції. На ринку спостерігається тенденція спаду: до 2008 р. наклад однієї назви в середньому становив 3 тис. прим., у сучасних умовах 1 тис. прим. Як наслідок, виробничі потужності завантажені менше ніж на 1/5.

Друкарня «Huss» досить стрімко розвивається та характери-

Таблиця 1

Виробнича потужність поліграфічних підприємств

\begin{tabular}{|c|c|c|c|c|c|c|}
\hline $\begin{array}{l}\text { № } \\
3 / \Pi\end{array}$ & $\begin{array}{c}\text { Підприєм- } \\
\text { ство }\end{array}$ & $\begin{array}{c}\text { Виробнича } \\
\text { потужність } \\
\text { додру- } \\
\text { карських } \\
\text { процесів, } \\
\text { форм }\end{array}$ & $\begin{array}{c}\text { Виробнича } \\
\text { потужність } \\
\text { друкарсь- } \\
\text { ких про- } \\
\text { цесів, тис. } \\
\text { умовних } \\
\text { фарбовідб. }\end{array}$ & $\begin{array}{c}\text { Рента- } \\
\text { бельність } \\
\text { виробничої } \\
\text { потужності, } \\
\%\end{array}$ & $\begin{array}{c}\text { Виробнича } \\
\text { потужність } \\
\text { післядру- } \\
\text { карських } \\
\text { процесів, } \\
\text { тис (книг, } \\
\text { журналів, } \\
\text { бланків, га- } \\
\text { зет) }\end{array}$ & $\begin{array}{c}\text { Коефіцієнт } \\
\text { викорис- } \\
\text { тання ви- } \\
\text { робничої } \\
\text { потужності }\end{array}$ \\
\hline 1 & Huss & 162647 & 321706,67 & 21 & 136362,35 & 0,053 \\
\hline 2 & Бліц-Принт & 237714 & 2184790,02 & 35 & 547854,06 & 0,12 \\
\hline 3 & Техніка-лтД & - & 102492,76 & 16 & 9259,85 & 0,02 \\
\hline 4 & Новий Друк & 135431 & 1328998,93 & 46 & 535522,51 & 0,079 \\
\hline 5 & Дніпрокварц & CTF 16948 & 66237,78 & 11 & 12343,08 & 0,045 \\
\hline 6 & $\begin{array}{c}\text { Укрполіграф- } \\
\text { медіа }\end{array}$ & 133121 & 386681,9 & 12 & 73115,13 & 0,064 \\
\hline 7 & $\begin{array}{c}\text { Кагарлицька } \\
\text { друкарня }\end{array}$ & CTF 22024 & 38133,32 & 10 & 2311,11 & 0,027 \\
\hline 8 & $\begin{array}{c}\text { Бізнес- } \\
\text { Поліграф }\end{array}$ & 11886 & 78188,48 & 18 & 28302,18 & 0,03 \\
\hline 9 & $\begin{array}{c}\text { Київська оф- } \\
\text { сетна фаб- } \\
\text { рика }\end{array}$ & 121083 & 161939,39 & 27 & 2447,06 & 0,065 \\
\hline
\end{tabular}


зується парком прогресивного устаткування. Ступінь використання виробничої потужності невисокий $-21 \%$. Втім явище тимчасове, оскільки друкарня демонструє стабільну позитивну динаміку обсягу виробництва, реалізована нею концепція збільшення частки на ринку довела свою життєздатність.

Технічний парк «Київської офсетної фабрики» торік поповнився новою високопродуктивною друкарською машину, що значно збільшило виробничу потужність. Але поки що є значний резерв у портфелі замовлень - 73 \%. Аналіз політики підприємства - розширення номенклатури продукції, активна і переважно успішна участь у конкурсах на державні закупівлі, - дозволяє зробити по- зитивний прогноз динаміки ступеня використання виробничої потужності.

Крім основних показників було також розраховано коефіцієнт пропорційності між цехами за такою методикою:

1. Для цеху із мінімальною пропускною спроможністю за назвами $\mathrm{K}_{\text {проп }}=1$.

2. Коефіцієнт пропорційності

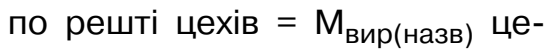
$\mathrm{xy} / \mathrm{M}_{\text {вир(назв) }}$ по цеху 3 мінімальною пропускною спроможністю.

Остаточні розрахунки подані у табл. 2.

Цехи підприємства завантаженні нерівномірно. Найбільш трудомісткими $є$ друкарські процеси. Тому, при плануванні виробничої потужності необхідно передбачати заходи, направлені: з одного боку - на роз-

Таблиця 2

Коефіцієнт пропорційності між цехами

\begin{tabular}{|c|c|c|c|c|}
\hline $\begin{array}{c}\text { № } \\
3 / п\end{array}$ & $\begin{array}{c}\text { Коефіцієнт про- } \\
\text { порційності до- } \\
\text { друкарського } \\
\text { цеху }\end{array}$ & $\begin{array}{c}\text { Коефіцієнт про- } \\
\text { порційності дру- } \\
\text { карського цеху }\end{array}$ & $\begin{array}{c}\text { Коефіцієнт про- } \\
\text { порційності } \\
\text { післядру- } \\
\text { карського цеху }\end{array}$ \\
\hline 1 & Huss & 25,2 & 1 & 28,3 \\
\hline 2 & Бліц Принт & 29,3 & 1 & 36,2 \\
\hline 3 & Техніка лтд & 42,8 & 1 & 17,6 \\
\hline 4 & Новий Друк & 15,8 & 1 & 37,5 \\
\hline 5 & Дніпрокварц & 47,4 & 1 & 23,7 \\
\hline 6 & Укрполіграфмедіа & 29,7 & 1 & - \\
\hline 7 & Кагарлицька друкарня & 56,7 & 1 & 17,2 \\
\hline 8 & Бізнес-Поліграф & 19,1 & 1 & 34,7 \\
\hline 9 & $\begin{array}{c}\text { Київська офсетна фаб- } \\
\text { рика }\end{array}$ & & & \\
\hline
\end{tabular}


шивку «вузьких місць» (збільшення потужності), а з іншого на завантаження потужності. Це необхідно для виявлення невідповідності виробничих потужностей окремих підрозділів прийнятій потужності по даних провідних цехах, а також для забезпечення технологічної пропорційності між взаємопов'язаними виробничими ланками.

\section{Висновки}

Проаналізувавши виробничу потужність обраних друкарень можна виявити її використання менш ніж на $50 \%$, що вказує на переважання наявного потенціалу над реалізованим. Ступінь використання потужностей між обраними підприємствами досить відрізняється, найбільші підприємства мають найвищі показники, хоча повністю і не задовольняються. Встановлено, що зв'язок між величиною виробничої потужності і ступенем ії використання $€$ істотно тісним (77\%).

Основною проблемою підприємств $€$ організація інтенсивного використання виробничих потужностей підприємств, a саме мобілізація резервів підвищення пропорційності потужностей шляхом вдосконалення побудови системи машин окремих підрозділів та підприємств у цілому, впровадження нової техніки і технології, раціональному використанні виробничих потужностей. Доцільно залучати замовлення по кооперації на виконання додрукарських та післядрукарських операцій.

1. Белов М. А. Планування діяльності підприємства [Текст] : Навч.-метод. посібник для самост. вивч. дисц. / М. А. Белов, Н. М. Євдокимова, В. Є. Москалюк та ін.; за заг. ред. В. Є. Москалюка. - К. : КНЕУ, 2002. - 252 с. 2. Зінь Е. А. Планування діяльності підприємства [Текст] : Підручник / Е. А. Зінь, М. О. Турченюк. - К. : ВД «Професіонал», 2004. - 320 с. 3. Мельник Л. Г. Экономика предприятия [Текст]: учеб. пособ. / Л. Г. Мельник. - Сумы : ИТД Университетская книга, 2002. - 632 с. 4. Петрович Й. М. Економіка виробничого підприємства [Текст] : навч. посіб. / Й. М. Петрович. - К. : Тво «Знання», 2002. - 405 с. 5.Петрович И. М. Производственная мощность и экономика предприятия [Текст] : учеб. пособ. / И. М. Петрович, Р. П. Атаманчук. - М., 1990. 6. Подкропивний С. Ф. Економіка підприємства [Текст] : Підручник / С. Ф. Подкропивний. - Вид. 2-ге, перероб. та доп. - К. : КНЕУ, 2001. - 528 с. 7. Руденко А. И. Экономика предприятия [Текст] : Учебник для экономических вузов / А. И. Руденко. - Минск, 1995. 8. Скляренко В. К. Экономика предприятия [Текст] : Конспект лекций / В. К. Скляренко, В. М. Прудников. - М. : Инфа-М, 2001. - 208 с. 9. Тарасюк Г. М. Планування діяльності підприємства [Текст] : Навч. посіб. / Г. М.Тарасюк, Л. І. Шваб. К. : Каравела, 2003. - 432 с. 10. Хрипач В. Я. Экономика предприятия [Текст] : учеб. пособ. / В. Я. Хрипач. - Минск, 1997. - 351 с. 11. Шегда А. В. Економіка підприємства [Текст] : навч. посіб. / А. В. Шегда. - К. : Знання, 2005. -431 с. 